Volume 19, No 3 International Journal of Radiation Research, July 2021

\title{
Radiological assessment on Caesium-137 (137Cs) radionuclide contamination from metal recycling facility and its surrounding environment, South - South Nigeria
}

\author{
I. Sambo* and G.B. Ekong* \\ Department of Radiological Safety, Nigerian Nuclear Regulatory Authority, Plot 564/565 Airport Road, Central \\ Business District, Garki, Abuja, FCT, Nigeria
}

\section{- Original article}

\section{*Corresponding authors:}

Isa Sambo, Ph.D.,

E-mail: isasambo@yahoo.com

Godwin Ekong, Ph.D.,

E-mail:gobass04@yahoo.com

Revised: July 2020

Accepted: August 2020

Int. J. Radiat. Res., July 2021; 19(3): 599-606

DOI: $10.29252 /$ ijrr.19.2.599

\begin{abstract}
Background: Radioactive material through scrap metal dealers, is often sold to steel processing facilities, which contaminate products with associated waste ends up in the environment. This study was to conduct radiological assessment of ${ }^{137} \mathrm{Cs}$ contaminated at metal processing facility and surrounding environment at Southern Nigeria as a function of time. Materials and Method: Samples were randomly collected within the facility and at surrounding environment, and analyzed using HpGe detector. Results: The ${ }^{137} \mathrm{Cs}$ concentration ranged $(1.61 \pm 0.25-2619.35 \pm 133.80) \mathrm{Bq} / \mathrm{g}$, with mean of $417.17 \pm 23 \mathrm{~Bq} / \mathrm{g}$. The ${ }^{137} \mathrm{Cs}$ concentration at 500 meters from the facility ranged $(0.21 \pm 0.02-3.63 \pm 0.25) \mathrm{Bq} / \mathrm{g}$ with the mean of $1.30 \pm 0.16 \mathrm{~Bq} / \mathrm{g}$. The ${ }^{137} \mathrm{Cs}$ concentration in the facility was above admissible limit of $100 \mathrm{~Bq} / \mathrm{g}$ except that recorded at 500 meters away. The radiological hazards within the first year were estimations, which showed Dose through Inhalation Pathways was $6.89 \times 10^{-3} \mathrm{mSv} / \mathrm{yr}$. Dose through Soil Ingestion Pathways was $0.91 \mathrm{mSv} / \mathrm{yr}$, and Sum External Dose from all the Pathways to be $1.44 \times 10^{3} \mathrm{mSv} / \mathrm{yr}$. The sum of evaluated radiological risk was found to be higher than the $0.25 \mathrm{mSv} / \mathrm{yr}$ or $1 \mathrm{mSv} / \mathrm{yr}$ admissible limits. An evaluated Excess Life Cancer Risk was found to be 2.5 quite above admissible limit of $\left(029 \times 10^{-3}\right)$. Conclusion: It is inferred from the assessment that, there is a likelihood of radiological health risk due ${ }^{137} \mathrm{Cs}$ contaminated to workers, public and other biota. Therefore, immediate remediation is recommended and as well as restrictions of the public using materials from the area for soil stabilization and farming purpose.
\end{abstract}

Keywords: Cesium-137, radioactive contamination, metal recycling.

\section{INTRODUCTION}

Variety of human activities can result in concentration of radioactive materials in the environment through process products and by-products waste streams.

Some of these activities are oil exploration, mining and milling of ores, scrap metal recycling/steel processing plants, waste treatment, some consumer products and nuclear reaction activities (1). Also, nuclear activities have similar tendencies to increase radiation level on earth through controlled operation, premeditated discharges or accident, and some abandon or orphan radioactive sources. Contaminated radioactive materials especially metals from these activities find their way as scraps to steel reprocessing facilities, thus its generated waste and contaminated products that are subsequently released to the environment $(2,3)$.

In the above regards, this has become radiation protection concern for both workers and public as this contamination environmental 
media, finds its way to human body through several exposures pathways of inhalation, ingestion and skin absorption, and which ends up irradiating tissues or organs of the body. The resultant effect of this may likely cause impairment, permanent alteration and possible death of the cells (3-6).

An artificial radionuclide under consideration capable of contaminating the environment is ${ }^{137} \mathrm{Cs}$, which is one radionuclide that may probably emanate from atmospheric nuclear weapons test, nuclear accident, scrap metal recycling facility, or indirect processes from sequential beta decay of precursor radionuclides, produced in the fission process of ${ }^{137} \mathrm{Te}$ decays to ${ }^{137} \mathrm{Cs}$, which has a relatively long half-life of 30.07 years. The ${ }^{137} \mathrm{Cs}$ during its release may spread into the stratosphere and troposphere, and gradually returns to the earth after a long while and thus contaminating the environment (7-9).

Several other pathway routes by which ${ }^{137} \mathrm{Cs}$ radionuclides contamination may get the human and environment are airborne deposition by atmospheric release, re-suspension of dust particles, runoff erosion via rainfall and root uptake by plants through food chain process $(10$, 11). The easy uptake of ${ }^{137} \mathrm{Cs}$ radionuclide is because of its solubility, and it is capable to replace ${ }^{40} \mathrm{~K},{ }^{22} \mathrm{Na}$ of Group I alkali metal element in the body mineral constituents, involved in ATPase pump or action potential, which disperses evenly in the body because of having same oxidation state, but of greater affinity $(9,12$, 13).

The aim of this study was to verify the presence and magnitude of ${ }^{137} \mathrm{Cs}$ contamination from defunct metal recycling facility wastes streams, evaluate its radiological hazards implication from present concentration level and assessed the contamination spread over 500 meters from the facility to surrounding environment. The uniqueness of this study was evaluating both the contamination level decaying and radiological impact decreasing process with respect to time that shall make for valuable input when considering decontamination and remediation purpose.

\section{MATERIALS AND METHODS}

\section{Instrumentation}

Major instruments used in this work are, GARMIN etrex 10 (GPS Finders - Serial number 3964), P-type Coaxial Hyper Pure Germanium detector (HpGe) detector at the Environmental Monitoring Laboratory of National Institute of Radiation Protection and Research (NIRPR), University of Ibadan, which has participated in inter-comparison analysis with other environmental analytical laboratories organised by the IAEA, Vienna, Austria.

The HpGe is a detector Canberra coaxial type, with $50 \%$ relative efficiency, and resolution of $2.4 \mathrm{keV}$ - at $1.33 \mathrm{MeV}$ of Co-60 was used. It is 8023 Model: Gc with Serial Number: 9744 and Pre Amplifier Model: 2002csl. The HpGe detector is well shielded by a lead shield, to protect from environment external radiation interference during measurement. The calibration of the HpGe detector was performed using IAEA calibration Multi-Gamma Ray Standard (MGS6M315) standards, to acquire spectrum peaks of radionuclides spanning through energy lines of ${ }^{241} \mathrm{Am}$ at $59.5 \mathrm{keV}$ to ${ }^{208} \mathrm{Tl}$ at $2614 \mathrm{keV}$, with which all other unknown radionuclides were dully detected and identified $(14,15)$.

\section{Sample collection}

The verification study were carried out at a defunct steel facility a steel processing/ metal recycling facility located at South - South Nigeria. A total of 32 samples of about $1 \mathrm{~kg}$ were collected each from different locations of Input stream (INSA), Processing stream casting points areas (PSCA), Waste stream slag Area (WSSA, WSSB for water samples), Waste stream fly ash (WSFA), few meters away from the facility (Control).

Also, total of 18 samples of about $1 \mathrm{~kg}$ were collected systematic random at 500 meters from the facility within every $100 \mathrm{ft}(33 \mathrm{~m})$ of each other. The areas with their designated codes were Front Gate (FG 1, FG2 etc), Right Side (RS1, RS2 etc), Outside Gate B (OGB1, OGB2 etc), Front Gate Water (FGW), and Water from River. 


\section{Preparation and analysis}

Samples preparations were carried out using standard procedures and dried at about $150^{\circ} \mathrm{C}$ to remove moisture. Samples were sieved using 500 ym mesh to ensure homogeneity and reduce tendency of undesirable attenuation during measurement. Samples that could not be sieved directly were sent for pulverization; about 0.65 $\mathrm{kg}$ of each sample was packed, sealed and labeled in a cylindrical Marinelli beaker that has provision to sit directly on the detectors cap. Samples were not stored to attain secular equilibrium since they were considered as hot samples because of anticipated artificial radionuclide; and were then counted for 18,000 seconds with $\mathrm{HpGe}$ detector.

Efficiency of the HpGe detector was estimated using the standard IAEA source to calibrate the detector prior to sample analysis. The absolute efficiency $\left(\varepsilon_{\gamma}\right)$ of a HpGe detector at specific gamma energy is given by equation $1,(16)$.

$\varepsilon_{Y}=\frac{c_{n e t}}{A \times I I_{Y}}$

Where; $A$ is the activity in $B q$ of gamma ray sources used in calibration and $I \gamma$ is absolute gamma decay intensity of specific energy peak (is the probability of emission per transformation for a photo peak specific energy).

Activity Concentration $\left(A_{c}\right)$ was calculated from analyzed using the equation 2 , (16) as:

$A_{c}=\frac{\mathrm{c}_{\mathrm{net}}}{s_{\mathrm{Y}} \times \mathrm{I}_{\mathrm{Y}} \times \mathrm{m}}$

Where; mass of the sample is denoted as $m$ in the expression. The unit of activity concentration of soil sample is given as $\mathrm{Bq} / \mathrm{g}$.

The decay rate of these nuclides concentration is proportional to the amount of atoms present at the time and the decay constant of the nuclide. This is given by equation 3:

$\mathrm{dN} / \mathrm{dt}=-\lambda \mathrm{N}$

Where; $\mathrm{N}$ is the number of atoms present, $\lambda$ is the decay constant, the negative sign indicating decrease of $\mathrm{N}$ time $(\mathrm{t})$. The decay constant is associated to half-life (which is time required a nuclide to decay by half its original state and often designated as $t_{1 / 2}$. This is given by equation 4 :

$\lambda=\operatorname{Ln} 2 / t_{1 / 2}$

Where; there are $\mathrm{N}_{0}$ atoms and $\mathrm{t}=0$, equation 3 , $(14,15)$ becomes

$\mathrm{N}=\mathrm{N}_{0} \exp ^{(-\lambda t)}$

\section{Radiological hazards evaluation}

Recently, in a bid to make available consistent foundation for radiation dose evaluations, studies supporting contemporary IAEA and ICRP handbook on reference or parameter values use in assessing transfer of radionuclides from soil-root transfer, anatomical and physiological data have been released for studies and references. These transfer factors are incorporated into codes like FRAME, PC-CREAM, ERICA, ECOLEGO, RESRAD etc. and used for radiological assessments.

The verification and validation from analysed results with RESRAD codes were employed for radiological evaluation of associated hazards/ impacts of this study. These codes have been expansively tried in an inter- comparison analysis with about seven other models in the world, and have been proven to be the most effective tools for environmental radiological risk assessment tool for contaminated sites and radiological situations (17).

The RESRAD code is computer software which incorporates all radiological inbuilt parameters like radionuclides data, derivation constants/concentration coefficients, regulatory limits /constraints and conditions etc. The analysis results obtained from the laboratory are imputed into the code fields for a particular type of desire results; the programme is allowed to run for specified time making use of inbuilt parameters and the results are generated. These results can be obtained in data form as in table 3 or graphical plots as in figures 1-3. 


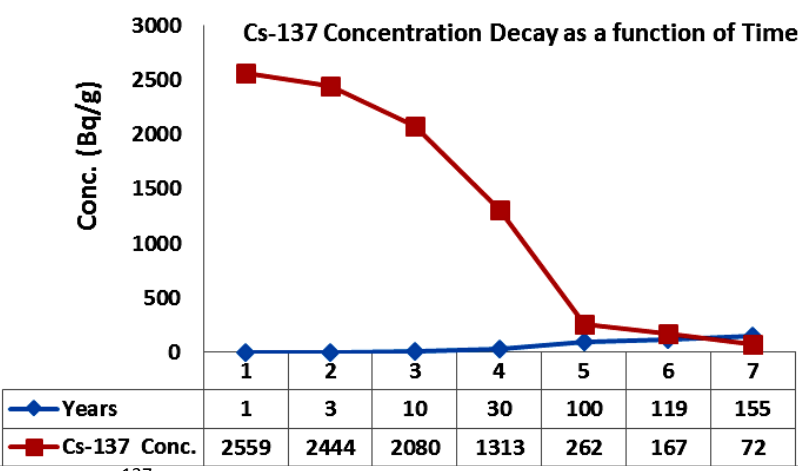

Figure $1 .{ }^{137} \mathrm{Cs}$ concentration contamination decay graph from maximum concentration as a function of time.

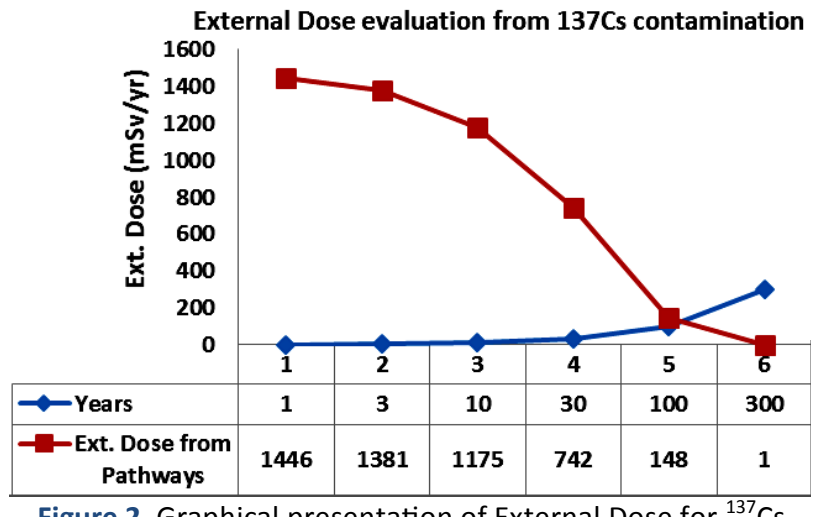

Figure 2. Graphical presentation of External Dose for ${ }^{137} \mathrm{Cs}$ contamination from pathways as a function of time.

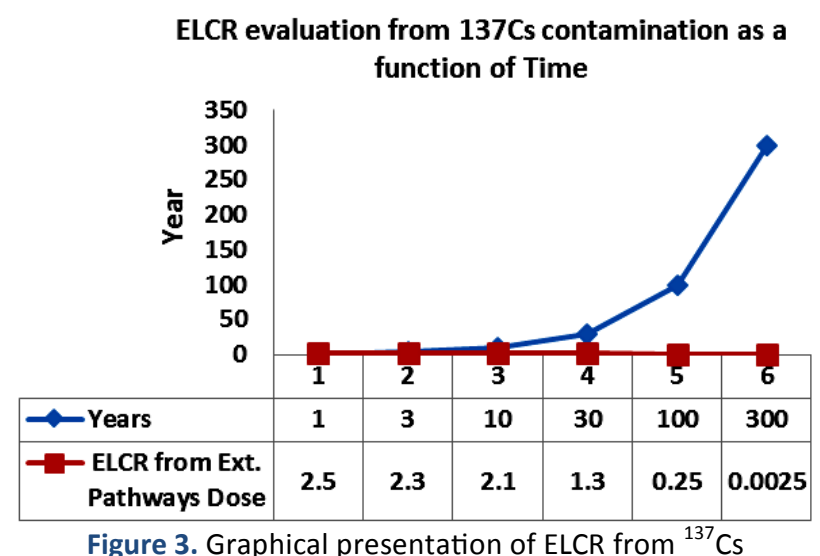

Figure 3. Graphical presentation of ELCR from ${ }^{137} \mathrm{Cs}$ contamination from sum of all pathways as a function of time.

\section{RESULTS}

The activity concentration $(\mathrm{Bq} / \mathrm{g})$ of ${ }^{137} \mathrm{Cs}$ was evaluated using equation 2 , for analysed samples and current concentration evaluated using Equation 5 as presented in table 1 . The concentration of INSA was found to be $259.80 \pm 13.34$, PSCA was $156.81 \pm 8.12$, WSSA was $158.26 \pm 8.18$, WSSB was $1.81 \pm 0.26$, and WSFA was $1248.99 \pm 63.86$. The ranged of ${ }^{137} \mathrm{Cs}$ radionuclides contamination for the analysed samples in the facility area was between $(1.76 \pm 0.27-2868.56 \pm 146.53) \mathrm{Bq} / \mathrm{g}$ with mean of $881.76 .56 \pm 45 \mathrm{~Bq} / \mathrm{g}$, while the current evaluated concentration was between (1.61 $\pm 0.25-2619.35 \pm 133.80) \mathrm{Bq} / \mathrm{g}$, with mean of $417.17 \pm 23 \mathrm{~Bq} / \mathrm{g}$. table 1 presents the activity concentration $(\mathrm{Bq} / \mathrm{g})$ of ${ }^{137} \mathrm{Cs}$ concentration from analysed samples of different locations and Control.

Also, the activity concentration $(\mathrm{Bq} / \mathrm{g})$ of ${ }^{137} \mathrm{Cs}$ was evaluated using equation 2 , for analysed samples and current concentration was evaluated using Equation 5 for analysed samples results at 500 meters from the facility to the surrounding environment as presented in table 2. The. The concentration of the analysed samples for ${ }^{137} \mathrm{Cs}$ radionuclides were between $(0.23 \pm 0.02-3.97 \pm 0.27) \mathrm{Bq} / \mathrm{g}$ with mean of $1.42 \pm 0.17 \mathrm{~Bq} / \mathrm{g}$, and current evaluated result was between $(0.21 \pm 0.02-3.63 \pm 0.25) \mathrm{Bq} / \mathrm{g}$ with the mean of $1.30 \pm 0.16 \mathrm{~Bq} / \mathrm{g}$.

The radiological hazard implications arising from the current maximum ${ }^{137} \mathrm{Cs}$ concentration of $2619.35 \mathrm{~Bq} / \mathrm{g}$ were evaluated using RESRAD (ONSITE) family codes from pathway parameters of Sum External Dose from all Pathways, Sum Excess Life Cancer Risk (ELCR) from all Pathways, Dose through Inhalation Pathways, Dose through Soil Ingestion Pathways as a function of time, and result of the evaluation is presented in table 3 . 
Table 1. Analysed and evaluated ${ }^{137} \mathrm{Cs}$ radionuclides concentration from the verification study.

\begin{tabular}{|c|c|c|c|c|}
\hline Sample type & Sample code & Dose rate (USv/h) & $\begin{array}{l}\text { Activity concentration } \\
\text { at } 2016(\mathrm{~Bq} / \mathrm{g})\end{array}$ & $\begin{array}{c}\text { Present activity } \\
\text { concentration }(\mathrm{Bq} / \mathrm{g})\end{array}$ \\
\hline$B G$ & - & $0.07 \pm 0.01$ & - & - \\
\hline \multirow{2}{*}{$\begin{array}{c}\text { SOIL - } \\
\text { CONTROL }\end{array}$} & CON 01 & $0.50 \pm 0.03$ & ND & ND \\
\hline & CON 02 & $0.09 \pm 0.02$ & ND & ND \\
\hline \multirow{2}{*}{$\begin{array}{c}\text { SOIL - INPUT } \\
\text { AREA }\end{array}$} & INSA 01 & $0.06 \pm 0.02$ & $70.44 \pm 3.69$ & $64.32 \pm 3.37$ \\
\hline & INSA 02 & $0.05 \pm 0.02$ & $498.60 \pm 25.53$ & $455.28 \pm 23.31$ \\
\hline \multirow{10}{*}{$\begin{array}{c}\text { SOIL - } \\
\text { PROCESSING } \\
\text { CASTING } \\
\text { AREA }\end{array}$} & PSCA 01 & $0.09 \pm 0.01$ & $99.59 \pm 5.20$ & $90.94 \pm 4.75$ \\
\hline & PSCA 02 & $0.10 \pm 0.01$ & $208.39 \pm 10.77$ & $190.28 \pm 9.83$ \\
\hline & PSCA 03 & $0.11 \pm 0.01$ & $830.07 \pm 42.44$ & $757.95 \pm 38.75$ \\
\hline & PSCA 04 & $0.12 \pm 0.01$ & $57.77 \pm 3.06$ & $52.75 \pm 2.79$ \\
\hline & PSCA 05 & $0.12 \pm 0.01$ & $320.48 \pm 16.47$ & $292.64 \pm 15.04$ \\
\hline & PSCA 06 & $0.12 \pm 0.01$ & $4.15 \pm 0.42$ & $3.79 \pm 0.39$ \\
\hline & PSCA 07 & $0.15 \pm 0.01$ & $33.27 \pm 1.85$ & $30.38 \pm 1.69$ \\
\hline & PSCA 08 & $0.14 \pm 0.01$ & $131.11 \pm 6.80$ & $119.72 \pm 6.21$ \\
\hline & PSCA 09 & $0.14 \pm 0.01$ & $7.60 \pm 0.55$ & $6.94 \pm 0.50$ \\
\hline & PSCA 10 & $0.13 \pm 0.01$ & $24.85 \pm 1.36$ & $22.69 \pm 1.24$ \\
\hline \multirow{8}{*}{$\begin{array}{c}\text { SOIL - WASTE } \\
\text { STREAM FLY } \\
\text { ASH AREA }\end{array}$} & WSFA 01 & $0.44 \pm 0.06$ & $2114.13 \pm 107.99$ & $1930.46 \pm 98.61$ \\
\hline & WSFA 02 & $0.32 \pm 0.01$ & $37.93 \pm 2.09$ & $34.64 \pm 1.91$ \\
\hline & WSFA 03 & $0.22 \pm 0.02$ & $2733.29 \pm 139.62$ & $2495.83 \pm 127.49$ \\
\hline & WSFA 04 & $0.15 \pm 0.02$ & $411.68 \pm 21.11$ & $375.91 \pm 19.28$ \\
\hline & WSFA 05 & $0.21 \pm 0.04$ & $1537.75 \pm 78.63$ & $1404.15 \pm 71.80$ \\
\hline & WSFA 06 & $0.17 \pm 0.03$ & $84.08 \pm 4.41$ & $82.69 \pm 4.74$ \\
\hline & WSFA 07 & $1.21 \pm 0.02$ & $1155.15 \pm 59.06$ & $1054.80 \pm 53.93$ \\
\hline & WSFA 08 & $0.45 \pm 0.03$ & $2868.56 \pm 146.53$ & $2619.35 \pm 133.80$ \\
\hline \multirow{8}{*}{$\begin{array}{c}\text { SOIL - WASTE } \\
\text { STREAM SLAG } \\
\text { AREA }\end{array}$} & WSSA 01 & $0.09 \pm 0.01$ & $369.35 \pm 18.94$ & 337.2617 .30 \\
\hline & WSSA 02 & $0.11 \pm 0.02$ & $63.18 \pm 3.33$ & $57.69 \pm 3.04$ \\
\hline & WSSA 03 & $0.10 \pm 0.02$ & $33.40 \pm 1.82$ & $30.50 \pm 1.66$ \\
\hline & WSSA 04 & $0.09 \pm 0.02$ & $55.19 \pm 2.92$ & $50.39 \pm 2.67$ \\
\hline & WSSA 05 & $0.10 \pm 0.02$ & $133.91 \pm 6.94$ & $122.28 \pm 6.34$ \\
\hline & WSSA 06 & $0.11 \pm 0.02$ & $472.30 \pm 24.27$ & $431.27 \pm 22.16$ \\
\hline & WSSA 07 & $0.11 \pm 0.02$ & $223.72 \pm 11.53$ & $204.29 \pm 10.53$ \\
\hline & WSSA 08 & $0.11 \pm 0.02$ & $35.48 \pm 1.95$ & $32.40 \pm 1.78$ \\
\hline \multirow{2}{*}{ WATER } & WSSB 01 & $0.12 \pm 0.01$ & $1.76 \pm 0.27$ & $1.61 \pm 0.25$ \\
\hline & WSSB 02 & $0.12 \pm 0.01$ & $2.20 \pm 0.31$ & $2.01 \pm 0.28$ \\
\hline \multicolumn{3}{|c|}{ Minimum } & $1.76 \pm 0.27$ & $1.61 \pm 0.25$ \\
\hline \multicolumn{3}{|c|}{ Maximum } & $2868.56 \pm 146.53$ & $2619.35 \pm 133.80$ \\
\hline
\end{tabular}


Table 2. Measured activity concentration of collected samples at 500 meters from the facility.

\begin{tabular}{|c|c|c|c|c|}
\hline Sample type & Sample code & Dose rate (YSv/h) & AC. conc. at $2016(\mathrm{~Bq} / \mathrm{g})$ & Present ac. conc. (Bq/g) \\
\hline Soil & FG1 & $0.09 \pm 0.69$ & $1.24 \pm 0.21$ & $1.13 \pm 0.19$ \\
\hline Soil & FG2 & $0.08 \pm 0.00$ & $3.97 \pm 0.04$ & $3.63 \pm 0.04$ \\
\hline Soil & FG3 & $0.07 \pm 0.01$ & $1.30 \pm 0.25$ & $1.19 \pm 0.23$ \\
\hline Soil & FG4 & $0.07 \pm 0.01$ & $1.47 \pm 0.27$ & $1.34 \pm 0.25$ \\
\hline Soil & FG5 & $0.06 \pm 0.01$ & ND & \\
\hline Soil & FG6 & $0.08 \pm 0.00$ & $0.65 \pm 0.20$ & $0.59 \pm 0.18$ \\
\hline Soil & FG7 & $0.07 \pm 0.00$ & $2.04 \pm 0.27$ & $1.86 \pm 0.25$ \\
\hline Water & FGW1 & $0.07 \pm 0.00$ & ND & \\
\hline Soil & RS1 & $0.06 \pm 0.00$ & $1.05 \pm 0.24$ & $0.96 \pm 0.22$ \\
\hline Soil & RS2 & $0.06 \pm 0.00$ & $0.30 \pm 0.15$ & $0.27 \pm 0.14$ \\
\hline Soil & RS3 & $0.05 \pm 0.00$ & $1.23 \pm 0.24$ & $1.12 \pm 0.22$ \\
\hline Soil & RS4 & $0.05 \pm 0.00$ & ND & \\
\hline Soil & RS5 & $0.05 \pm 0.00$ & ND & \\
\hline Soil & OGB1 & $0.07 \pm 0.00$ & $1.58 \pm 0.21$ & $1.44 \pm 0.19$ \\
\hline Soil & OGB2 & $0.06 \pm 0.00$ & $1.53 \pm 0.18$ & $1.40 \pm 0.16$ \\
\hline Soil & OGB3 & $0.03 \pm 0.00$ & $0.84 \pm 0.15$ & $0.77 \pm 0.14$ \\
\hline Soil & OGB4 & $0.04 \pm 0.00$ & $1.14 \pm 0.02$ & $1.04 \pm 0.02$ \\
\hline Soil & OGB5 & $0.04 \pm 0.00$ & ND & \\
\hline $\begin{array}{c}\text { River Water } \\
\text { Behind }\end{array}$ & RWB1 & $0.06 \pm 0.00$ & $0.23 \pm 0.08$ & $0.21 \pm 0.07$ \\
\hline \multicolumn{3}{|c|}{ Minimum } & $0.23 \pm 0.02$ & $0.21 \pm 0.02$ \\
\hline \multicolumn{3}{|c|}{ Maximum } & $3.97 \pm 0.27$ & $3.63 \pm 0.25$ \\
\hline \multicolumn{3}{|c|}{ Average } & $1.42 \pm 0.17$ & $1.30 \pm 0.16$ \\
\hline
\end{tabular}

Table 3. Radiological Hazard Assessment arising from the ${ }^{137} \mathrm{Cs}$ concentration contamination as a function of time.

\begin{tabular}{|c|c|c|c|c|c|c|c|}
\hline Evaluating parameters & $\mathbf{1}$ Year & $\mathbf{3}$ Years & $\mathbf{1 0}$ Years & $\mathbf{3 0}$ Years & $\mathbf{1 0 0}$ Years & $\mathbf{1 5 5}$ Years & 300 Years \\
\hline${ }^{137}$ Cs Ave. Conc. (Bq/g) & $4.08 \times 10^{2}$ & $3.89 \times 10^{2}$ & $3.31 \times 10^{2}$ & $8.2 \times 10^{1}$ & $4.2 \times 10^{1}$ & 12 & 0.00 \\
\hline${ }^{137}$ Cs Max. Conc. (Bq/g) & $2.55 \times 10^{3}$ & $2.44 \times 10^{3}$ & $2.08 \times 10^{3}$ & $1.38 \times 10^{3}$ & $2.62 \times 10^{2}$ & 72 & 0.00 \\
\hline Sum Ext. Dose all Pathways (mSv/yr) & $1.44 \times 10^{3}$ & $1.38 \times 10^{3}$ & $1.18 \times 10^{3}$ & $7.88 \times 10^{2}$ & $1.48 \times 10^{2}$ & $1.21 \times 10^{2}$ & 1 \\
\hline Sum ELCR from all Pathways & 2.50 & 2.30 & 2.10 & 1.30 & 0.25 & 0.01 & 0.0025 \\
\hline Dose from Inhalation Pathways (mSv/yr) & $6.89 \times 10^{-3}$ & $6.55 \times 10^{-3}$ & $5.50 \times 10^{-3}$ & $3.50 \times 10^{-3}$ & $0.61 \times 10^{-3}$ & 0.00 & 0.00 \\
\hline Dose from Ingestion Pathways (mSv/yr) & 0.91 & 0.87 & 0.74 & 0.46 & 0.13 & 0.00 & 0.00 \\
\hline
\end{tabular}

\section{DISCUSSIONS}

It was observed from table 1 that, the highest contribution of ${ }^{137} \mathrm{Cs}$ concentrations of the facility came from the fly ash area with maximum value of $2619.35 \pm 133.80 \mathrm{~Bq} / \mathrm{g}$. The average concentration of $417.17 \pm 23 \mathrm{~Bq} / \mathrm{g}$ was much higher than admissible limits. The high concentrations above admissible limits of 100 $\mathrm{Bq} / \mathrm{g}$ signifies presence ${ }^{137} \mathrm{Cs}$ source which found its way to the scrap metal recycling facility thereby contaminating the entire process line $(7,11,18,19)$.

Evaluating ${ }^{137} \mathrm{Cs}$ concentration contamination as a function of time using RESRAD (ONSITE) family codes, reveals that by 155 years from now, the present maximum concentration of $2619 \pm 0.13 \mathrm{~Bq} / \mathrm{g}$ would have been reduced to clearance level of $72 \mathrm{~Bq} / \mathrm{g}$. Whereas the present average concentration of $417.17 \pm 23 \mathrm{~Bq} / \mathrm{g}$ would have been reduced to clearance level of $12 \mathrm{~Bq} / \mathrm{g}$ which will invariable results to insignificant radiological effect to both human and other biota and is graphically presented in figure 1 .

The activity concentration of ${ }^{137} \mathrm{Cs}$ radionuclides at 500 meters to the surrounding environment presented in table 2, were far below levels for exemption of bulk

Int. J. Radiat. Res., Vol. 19 No. 3, July 2021 
amounts and for clearance of solid material without further consideration as internationally recommended limit for metal recycling. These ${ }^{137} \mathrm{Cs}$ concentrations does not portray any radionuclide - soil transfer from the facility to the environment. However, the evaluation was imperative to create public assurance that no spread of the ${ }^{137} \mathrm{Cs}$ contamination had a likelihood to result in appreciable radiological risk to both flora and fauna of surrounding environment.

Some studies were conducted in some part of Nigeria with traces of ${ }^{137} \mathrm{Cs}$ concentration similar to that of 500 meters to the surrounding environment and were noted. An assessment of radioactivity content of food in the oil and gas producing areas in Delta State, Nigeria where an evaluated results for ${ }^{137} \mathrm{Cs}$ was between (0.27-2.4) Bq/g (22). Also, Radiological Baseline Assessment of proposed Nuclear Power Plant site in Itu, Akwa Ibom State Nigeria were ${ }^{137} \mathrm{Cs}$ concentration was $1.07 \pm 0.26 \mathrm{~Bq} / \mathrm{g}$. Although the concentration was below limit, but the presence of ${ }^{137} \mathrm{Cs}$ radionuclides calls for periodic monitoring to avoid accumulated effect of health hazards (23). These similar studies with traces of ${ }^{137} \mathrm{Cs}$ concentration portrays that the ${ }^{137} \mathrm{Cs}$ radionuclide may have emanated from fallout from nuclear test, which is likely to spread into stratosphere and troposphere, and gradually returning to the earth over time $(6,9,11,13)$.

The radiological hazard estimations using RESRAD (ONSITE) family of codes reveals that at the first year, sum external dose from all Pathways was found to be $1.44 \times 10^{3} \mathrm{mSv} / \mathrm{yr}$, dose through inhalation pathways was $6.89 \times 10^{-3}$ $\mathrm{mSv} / \mathrm{yr}$, and dose through soil ingestion pathways was $0.91 \mathrm{mSv} / \mathrm{yr}$. These evaluations were based on a conservative approached of $0.25 \mathrm{mSv} / \mathrm{yr}$ instead of $1 \mathrm{mSv} / \mathrm{yr}$ regulatory limits/ conditions, standard dose coefficient factors etc. (19-21) as presented in table 3 . However, the radiological risk evaluation was found to be much higher than the $0.25 \mathrm{mSv} / \mathrm{yr}$ or $1 \mathrm{mSv} / \mathrm{yr}$ admissible limits. Also, the evaluation of external dose for ${ }^{137} \mathrm{Cs}$ contamination from pathways as a function of time is graphically presented in figure 2 , and this reveals that by 300 years, the present external dose of $1446 \mathrm{mSv} / \mathrm{yr}$ would have been reduced to $1 \mathrm{mSv} / \mathrm{yr}$, which will equivalence to public annual effective dose and as presented in figure 2 .

Furthermore, the likelihood of cancer risk due to exposure to radiation in the location to any population was evaluated from Sum ELCR from all pathways, which was found to be 2.50 at the first year much higher than the admissible limits. Also, evaluating ELCR for ${ }^{137} \mathrm{Cs}$ concentration as a function of time as graphically presented in figure 3 , reveals that by 300 years, the present ECLR of 2.50 will reduce to $0.25 \times 10^{-3}$ and falls below the admissible limit of $0.29 \times 10^{-3}(21)$.

\section{CONCLUSIONS}

Radioactive materials through scrap metal dealers' activities find their way to steel processing facilities, and thereby contaminating the facility and environment through process products and associated waste streams. The study was to verify ${ }^{137} \mathrm{Cs}$ contamination at the metal processing facility, its surrounding environment and assess the radiological impact. The ${ }^{137} \mathrm{Cs}$ contamination was discovered to be high in the facility, and low at the surrounding environment translated to no radiological hazards to the public and other biota. Therefore, decontamination of the facility and periodic monitoring is advised.

\section{Conflicts of interest: Declared none.}

\section{REFERENCES}

1. US Environmental Protection Agency (2011) Radioactive equilibrium. Available at http://www.epa.gov/radiation/ understand/equilibrium.html, 2011. Last Assessed $20^{\text {th }}$ March 2019.

2. International Atomic Energy Agency (2005) Environmental and source monitoring for purpose of radiation protection, IAEA Safety Standard Series No. RS- G-1.8, IAEA, Vienna, Austria, 2005; 10-130.

3. International Atomic Energy Agency (2012) Control of orphan sources and other radioactive material in the met- 


\section{Sambo and Ekong / Radionuclide contamination from metal recycling facility}

al recycling and production Industries. IAEA safety standards for protecting people and the environment (SSG-17). Austria: Publication of International Atomic Energy Agency, 2012; STI/PUB/1509.

4. Njinga RL, Ibrahim YV, Ishoryiyi IJ (2015) Radioactivity analysis in underground drinking water sources in Niger state university of Nigeria, Pollution, 1(3): 315-324.

5. Little MP (2003) Risks associated with ionizing radiation. Environmental pollution and health British Medical Bulletin, (68)1: 259-275.

6. Martin A, HarbisonS, Beach K, Cole P (2012) An introduction radiation protection. Fifth Edition, Hodder Arnold, an imprint of Hodder Education, Hachette UK, 6 -209.

7. Ogundare FO and Nwankwo CU (2014) Radionuclide content of, and radiological hazards associated with samples from different streams of metal recycling facilities, Radioprotection, 50(1): 55-58.

8. International Atomic Energy Agency (2005) Radiological conditions at the former french nuclear test sites in algeria: preliminary assessment and recommendations. Radiological Assessment Report Series, IAEA, Vienna, Austria, 2005; 1-59.

9. Osouli A, Abbasi F, Naseri M (2009) Measurement of ${ }^{137} \mathrm{Cs}$ in soils of Tehran province. Int J Radiat Res, 7(3): 141-149.

10. Kolo MT, Amin YM, Khandaker MU, Abdullah WHB (2017) Radionuclide concentrations and excess lifetime cancer risk due to gamma radioactivity in tailing enriched soil around Maiganga coal mine, Northeast Nigeria. Int J Radiat Res, 15(1): 71-80.

11. International Atomic Energy Agency (2014) Radiation protection and safety of radioactive source. International Basic Safety Standard, General Safety Requirements Part 3, IAEA, Vienna, Austria, 1-110.

12. Waugh A and Grant A (2014) Ross and Wilson Anatomy \& Physiology in Health and Illness, International Edition, Churchill Livingstone Elservier, 147-148.

13. Ekong GB, Sambo I, Sayaidi S (2016) Determination of radionuclides surface concentration and radiation level in Fukushima prefecture, Japan. Modern Environmental
Science and Engineering, 2(1): 757-764.

14. Fasunwon $O$, Alausa $S$, Odunaike R, Alausa I, Sosanya F, Ajala B (2010) Activity concentrations of natural radionuclide levels in well waters of Ago Iwoye, Nigeria. Int J Radiat Res, 7(4): 207-210.

15. Knoll GF (2010) Radiation detection and measurement. Fourth Edition; John Wiley \& Sons, New York, 123- 506.

16. Dizman S and Keser R (2019) Natural radioactivity in ceramic tiles and associated radiological hazards. Int $\mathrm{J}$ Radiat Res, 17(2): 245-252.

17. Yu C (2018) Introduction to radiological dose assessment and RESRAD family of codes. Environmental Science Division, Argonne National Laboratory, USA Department of Energy, 2018; 1-22. Last accessed on $21^{\text {st }}$ May, 2018, Available at: $h t t p$, resrad.evs.anl.gov.

18. International Atomic Energy Agency (2011) Radiation protection and safety of radiation sources: International Basic Safety Standards. IAEA Safety Standard Series General Safety Requirement Part 3, IAEA, Vienna, Austria.,

19. International Commission on Radiological Protection (2007) The 2007 recommendations 103 of the international commission on radiological protection, ICRP publication, 2007.

20. United Nations Scientific Committee on the Effects of Atomic Radiation (UNSCEAR) (2000a) Exposures from natural radiation sources, Annex B New York, 2000a.

21. United Nations Scientific Committee on the Effects of Atomic Radiation (UNSCEAR) (2000b) Effects and risks of ionizing radiations. United Nations; New York, 2000b.

22. Tchokossa P, Olomo, JB, Balogun FA, Adesanmi CA (2013) An assessment of radioactivity content of food in the oil and gas producing areas in Delta State, Nigeria. International Journal of Science and Technology, 3(4): 245-250.

23. Ekong G, Akpa T, Umaru I, Samson D, Akpanowo MY, Benson $N$ (2021). Baseline radioactivity and associated radiological hazards in soils around a proposed nuclear power plant facility, South-south Nigeria. Journal of African Earth Sciences, https://doi.org/10.1016/j.jafrearsci.2021.104289 